\title{
Molecular characterization of drug sensitive and drug resistant strains of Salmonella typhi
}

\author{
R. Chaudhry ${ }^{1}$, D.S. Chandel ${ }^{1}$, G. Mehta ${ }^{2}$, H. Kapoor ${ }^{3}$, T. Pang ${ }^{4}$
}

\begin{abstract}
Abstrak
173 isolat S. typhi yang telah diidentifikasi dengan PCR diuji lebih lanjut untuk mengetahui profil antibiogram, MIC, profil plasmid serta analisis Pulsed-Field Gel Electrophoresis (PFGE). 36\% (63) dari isolat tersebut resisten terhadap satu atau lebih antibiotika. Dari persentase tersebut, $20 \%$ (35) resisten terhadap khloramfenikol (C) dan trimetoprim sulfametoksasol (Tm Su). Disamping resisten terhadap $C$ dan $T$ in Su, 4 isolat juga resisten terhadap amoksisilin $(A x) /$ gentamisin $(G)$ / sefotaksim (Cx). Dengan menggunakan E-strips (Biodisk) didapatkan MIC yang lebih tinggi terhadap Tm Su dan siprofloksasin. Isolat yang resisten terhadap C dan Tm Su berturut-turut memiliki MIC 32 dan $4 / 176 \mu \mathrm{g} / \mathrm{ml}$. Tiga galur dari grup yang moderat sensitif dan 2 galur dari grup yang sensitif terhadap siprofloksasin

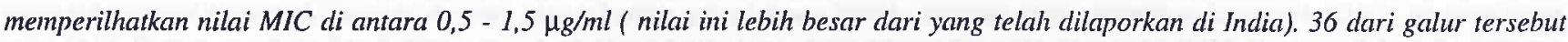
di atas dilakukan uji tipe faga, didapatkan bahwa sebagian besar termasuk faga grup EJ(17) dan (A3). Satu isolat termasuk faga grup $E, I 1$ isolat tidak dapat ditentukan tipe faganya, dan 3 isolat Vi negatif. Sebagian besar galur yang resisten termasuk faga tipe E. Dipilih beberapa galur (sensitif dan resisten) untuk diperiksa adanya plasmid. Plasmid berukuran 4-55 kb terdapat pada sebagian besar galur yang sensitif maupun yang resisten, sedangkan plasmid berukuran 90-180 kb terdapat pada galur yang resisten terhadap berbagai antibiotika (Multi Drug Resistance $=M D R$ ). Analisis dengan PFGE dari 20 isolat (baik yang sensitif maupun yang resisten) memperlihatkan pola PFGE yang heterogen di antara galur yang sensitif; sedangkan homogenitas dijumpai pada galur MDR dengan perkecualian 1 kasus. Analisis perbandingan dari pola PFGE menunjukkan bahwa terdapat keragaman genetik di antara galur-galur Salmonella.
\end{abstract}

\begin{abstract}
A total of 173 isolates of S. typhi identified by PCR were characterized by antibiogram profile, MIC determination, plasmid profile and PFGE analysis. 36\% of the isolates (63) were found to be resistant to one or more antibiotics. Of these 20\% (35) were resistant to Chloramphenicol $(C)$ and Trimethoprim Sulphamethoxazol (Tm Su) and also 4 isolates were resistant to amoxycillin (Ax)/gentamycin $(G)$ /cefotaxime $(C x)$ in addition to C and Tm Su. Higher MICs to Tm Su and Ciprofloxacin.were demonstrated using E-sirips (Biodisk). Isolates resistant to $C$ and $T m S u$ had MIC higher than 32 and $4 / 176 \mu g / m l$ respectively. 3 strains from moderately sensitive group and 2 from sensitive group against Ciprofloxacin showed MICs in the range of 0.5 to $1.5 \mu \mathrm{g} / \mathrm{ml}$ which is higher than $0.25 \mathrm{ug} / \mathrm{ml}$ reported so far from India. 36 of these strains were phage typed and most of them belonged to phage group EI(17) and (A3). One isolate was in phage group $E$, while 11 isolates were untypeable and 3 were Vi negative. Most of the resistant strains were in the phage type E, Representative strains (both sensitive \& resistant) were screened for the presence of plasmids in the range of 4-55 kb were present in most of the resistant as well as sensitive strains while plasmids of 90-180 kb were present in exclusively MDR strains. Pulsed-Field Gel Electrophoresis analysis of 20 (both sensitive \& resistant) isolates showed heterogeneity in PFGE patterns among drug sensitive strains while homogeneity among MDR strains except in one case. Comparative analysis of PFGE patterns suggested that considerable genetic diversity exists among Salmonella strains.
\end{abstract}

Dept. of Microbiology, A.I.I.M.S ${ }^{1}$, Lady Harding Medical College ${ }^{2}$,

S.J Hospital ${ }^{3}$, New Delhi, India.

Institute of Advance Studies, ${ }^{4}$ Kuala Lumpur, Malaysia. 